\title{
Customary Right Compensation and Forest Villages Development Programs of Mangrove Company at Bintuni Bay Papua Barat
}

\author{
Wahyudi*, Max Jondudago Tokede, Zulfikar Mardiyadi, Ana Tampang, Mahmud
}

Faculty of Forestry, State University of Papua, Gunung Salju Amban, Manokwari, Indonesia 98314

Received May 9, 2014/Accepted December 23, 2015

\begin{abstract}
Mangrove at Bintuni bay offers various services to indigenous communities from ecology, social, and economic. Mangrove also could be harvested accordingly to optimize contributions to indigenous communities welfares. This paper highlights implementation of customary right compensation (CRC), and Forest Villages Development programs (FVDP) of mangrove company at Bintuni Bay, Papua Barat. Company reports and documents related to CRC and FVDP from 1988 to June 2013 were reviewed and analyzed. Field works were conducted to examine the implementation of both programs at four villages of two districts. Sustained mangrove harvest for chipwood production in Bintuni bay for more than 25 years is the most outstanding achievement of mangrove utilization and management in Indonesia. Huge amount of expenditure have been spent out, and given to indigenous communities through the CRC and FVDP programs, respectively. These cover from economic, social, and environmental related programs, manufactured public facilities, scholarships, and others. However, the indigenous communities are remained poor, and failed of being self-sufficient community. It clearly impresses that the main goals to improve the welfare, prosperity of indigenous people are considerable failed. It is presumably that social culture systems, and subsistence agriculture practices contribute to the failing these programs. Mostly, forest communities in Papua are practicing subsistence agriculture, hunting, heavily relying on their surrounding natural resources, and spending all their cash or money instantly for consumption, not for saving, investments or even productive activities. Therefore, several program could be initiated to improve in achieving the CRC and FVDP missions, such as building capacity, providing counselors and strengthen local community governance, which could accelerate of being self-reliant community.
\end{abstract}

Keywords: customary right compensation, forest villages development, mangrove, Bintuni Bay

*Correspondence author, email: wahyudi.s.pono@gmail.com, tel./fax.: +62-986-211065

\section{Introduction}

Mangrove grows along coastal areas of tropical and subtropical countries around the world, and plays important roles to ecological, economical, and social functions; and these functions recently have been universally realized and acknowledged (Islam \& Wahab 2005). Mangrove still sustain productive, biologically unique, and economically important ecosystem for both local people and environments (Wang et al. 2008). However, these intangible values of mangrove goods and services, which vary for different areas, are limited or even neglected (Ong \& Gong 2013). The local or indigenous people living in or near mangrove areas derive their daily principal income, and fulfill their daily needs of fuel wood, construction material, food (fish, crab), honey bees, and hunted wildlife from this resources (Walters et al. 2008).

Previously, mangrove resources are being degraded or destroyed by human economic activities due to development and expansion for different purposes of agriculture, fishery, and infrastructure. These human economic activities result significantly lost of mangrove worldwide, and conservation organizations are highly opposed with these phenomenon
(Cullen et al. 2007). Utilization of mangrove resources for commercial purposes of timber harvesting for wood chip or charcoal, that allow long term economic, social, and ecological sustainability, are soundly feasible (Walter 2005). This utilization will initiate multiple impacts not only on mangrove resources management and sustainability, but also on social economic of local community, and conservation (Cullen et al. 2007). Commercial utilization, forest exploitation including harvesting mangrove resources is connecting tasks among management, conservation, and social economic development (Marfo \& Schannz 2009; Schoneveld 2014).

West Papua Province has mangrove resources of 430,616.00 ha (MoF 2011), mainly distributed at Bintuni Bay, Babo, Sorong Selatan, and Raja Ampat. From this area, 124.850,90 ha have been declared as Bintuni Bay Preserved Area (MoF Decree Number 891/1999). A mangrove company, Bintuni Utama Murni Wood Industries (BUMWI) Ltd, received forest concession right (hak pengusahaan hutan, $\mathrm{HPH}$ ) to harvest and manage mangrove forest at Bintuni Bay, scattering from Bomberai to Naramasa River of $137.000,00$ ha area for 20 years of 1988 to 2008 (MoF Decree Number 144/1988). 
In 2007, this mangrove company received a new Business Permit for Utilization of Timber Forest Product (izin usaha pemanfaatan hasil hutan kayu, IUPHHK), next abbreviated as timber company, scattering from Senindara to Naramasa river of 82.120,00 ha for the next 45 years of 1988 to 2053 (MoF Decree Number 213/2007). IUPHHK is given by Ministry of Forestry in order to increase the contribution of mangrove forest in rising government revenues, creating employment, distributing growth and development, improving quality life, and prosperity of indigenous people. The indigenous people are native people, who live in and or near the stated forest areas, and had heavily dependent on the forest (MoF Decree Number 523/1999), or forest-dependent communities (Engel \& Palmer 2006). The indigenous people are traditionally the ownership forest area and hold forest customary right (World Bank 2012). In Papua, including West Papua, indigenous people refer to native people, who live together under similar administrative system of village (kampung), and consisting of several clans (family name), whereas native clans are families who hold, inherited or ownership of the customary right of land or forest resources inherited from their ancestors (GoWP Decree Number 144 2007).

Similar to other non-timber companies, timber company has social and environmental obligation. One example of social obligation of timber company is to empower the indigenous people, and increase their welfare and living incomes (MoF Decree Number 671/1991; Number $523 / 1997$ ), and this program is widely known as forest village development program (FVDP), in Indonesian called as pembinaan masyarakat desa hutan (PMDH). FPDP are all efforts required and needed to improve livelihood quality, provide extra incomes, and improve social welfare to gain self-fulfilling needs and sustainable growth of forest people live in and or near the forest areas (MoF Decree Number P.01/2004). Therefore, FVDP covers broad activities of vegetable and fruits cultivation, intensive agriculture, rising domestic animal, fishery, and the others.

For these purposes, timber company and FMU have to allocate IDR1,000.00 $\mathrm{m}^{3}$ of log being harvested (MoF Decree Number 165/1988). Besides FVDP, the timber company and FMU have another obligation to empower dependent forest community (Engel \& Palmer 2006), or the native who owned and inherited traditional customary right of forest areas. This obligation is namely customary right compensation (CRC), logging rent or property right over customary (adat) forest (Engel \& Palmer 2006) and utilization right (Nomura 2008). $\mathrm{CRC}$ is compensation from timber companies to the native clans because of reduction in forest quality, limitation of accessibility, and disturbances of the daily livelihood of forest people. The value of CRC for mangrove $\log$ is IDR6,000.00 $\mathrm{m}^{3}$, significantly different to Merbau (Instia spp.) and Matoa (Pometia spp.), which are of IDR60,000.00, and IDR25,000.00 for merbau and matoa, respectively (GoWP Decree Number 144/2007).

Timber companies and or FMU operated both in Papua and West Papua Province, therefore, have two social and environmental obligations, namely CRC and FVDP, respectively (Yeny \& Innah 2007). Both programs have different recipients. The main beneficiaries of CRC are only the native clans or ownership of customary right of mangrove forest being harvested. Whereas, FVDP is delivered to all indigenous community live in and or near areas of mangrove concession (BUMWI 2008).

This research is designed to study implementation of customary right compensation and FVDP of mangrove company during its operation at Bintuni Bay, West Papua. Social, economic, and environmental contributions of mangrove operation on the indigenous community livelihood, as well their perspective and view, were also qualitatively reported. This paper will briefly highlight the measurable combination among social, economic, and environmental management to sustain mangrove utilization in Bintuni Bay, and share these lesson learned to the readers.

\section{Methods}

Data were collected from the CRC and FVDP documents, company annual reports, and other related documents from 1988 to 2013 June, and then reviewed and analyzed. Field works were conducted to ensure the physical implementation of the CRC and FVDP at the indigenous community villages. Four villages represent the holders of customary right at 2 districts were selected. Questioners and interviews were used to gather all data using computer program Microsoft Excel used to analyze and interpret data, and presented in tables and figures.

This research was taken place at Base Camp at Amutu Besar Island and 4 villages of 2 districts in mangrove concession area under Bintuni Bay Regency, Papua Barat Province. This research was conducted in July 2013.

\section{Results and Discussion}

For the simplicity and understandable interpretation, the results are organized here into five sections as follows: (1) customary right compensation, (2) forest village development programs, (3) social related programs, (4) perceptions of indigenous community on BUMWI Ltd, and (5) impact of mangrove operation on social economic of indigenous community.

Customary right compensation (CRC) Document review and analysis indicated that expenditure spent for customary right compensation could be grouped into 2 time series or period, from 1988-2010 and 2011-2013. On the first time series, expenditure, receipts, and other proven pictures were not well documented or binder less. In contrast, the second time series of 2011-June 2013, all receipts, expenditure, pictures, and any supporting papers were well organized on the binding documents. Presumably, these systematized documents and expenses papers due to assistances from the auditor teams when assessment for implementation sustainable forest management (pengelolaan hutan produksi lestari, PHPL) and chain of custody (verifikasi legalitas kayu, VLK) on this company were undertaken. Two achievement certificates, sustainability forest management and chain of custody, respectively, have been awarded by two independent auditors (Sarbi 2011; SCS 2013) to PT BUMWI for harvesting and managing mangrove resources at Bintuni Bay for chip production (Wahyudi 2013). 
Summary of the reviewed and analyzed documents of CRC from 1998-2010 is presented in Figure 1. As been illustrated in Figure 1, the CRC has been given to the native clans from 1990 to 2010 without absent or delayed. The CRC worth increases substantially from IDR $33,150,000.00$ in 1990, and exceed to IDR339,596,804.00 in 2010, and at this period, the highest worth was in 2007 (IDR365,327,050.00). For 2011 to June 2013, a period when this research was taking place, the total compensation given to the native clans in 2012 (IDR726,913,920.00) was higher than that in 2011 (IDR684,446,940.00), and for 2013 up to June, it reaches into IDR233,054,400.00 (Figure 2). The fluctuations of compensation are highly related to the volume of mangrove log being harvested from the forest. The amounts of compensation are not negotiable, but it is accounted by the forest manager using unit value per meter cubic $\log$ (GoWP Decree 144/2007). It is slightly different to the land right community forest in Riau and South Kalimantan (Nugroho 2011), and oil palm development customary land in Sarawak (Cramb 2013). They reported that the local community has a power to negotiate compensation in term of value per cubic meter $\left(\mathrm{m}^{3}\right)$, or type of compensation.

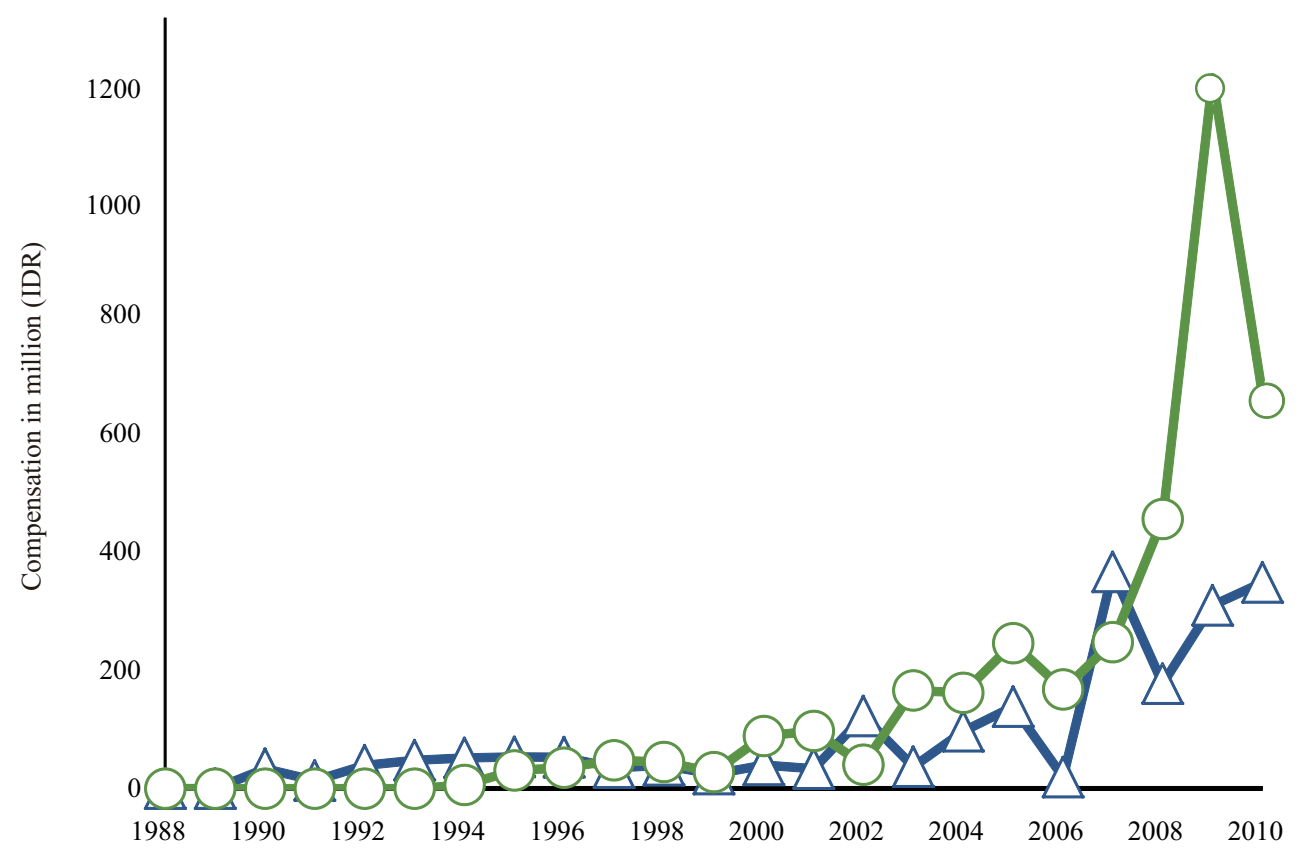

Figure 1 Expenses spent for customary right compensation and forest village development programs of BMUWI Ltd from 1988 to 2010. Forest village development program (FVDP $)(\longrightarrow-$ - customary right compensation $(\mathrm{CRC})(\longrightarrow \triangle)$.

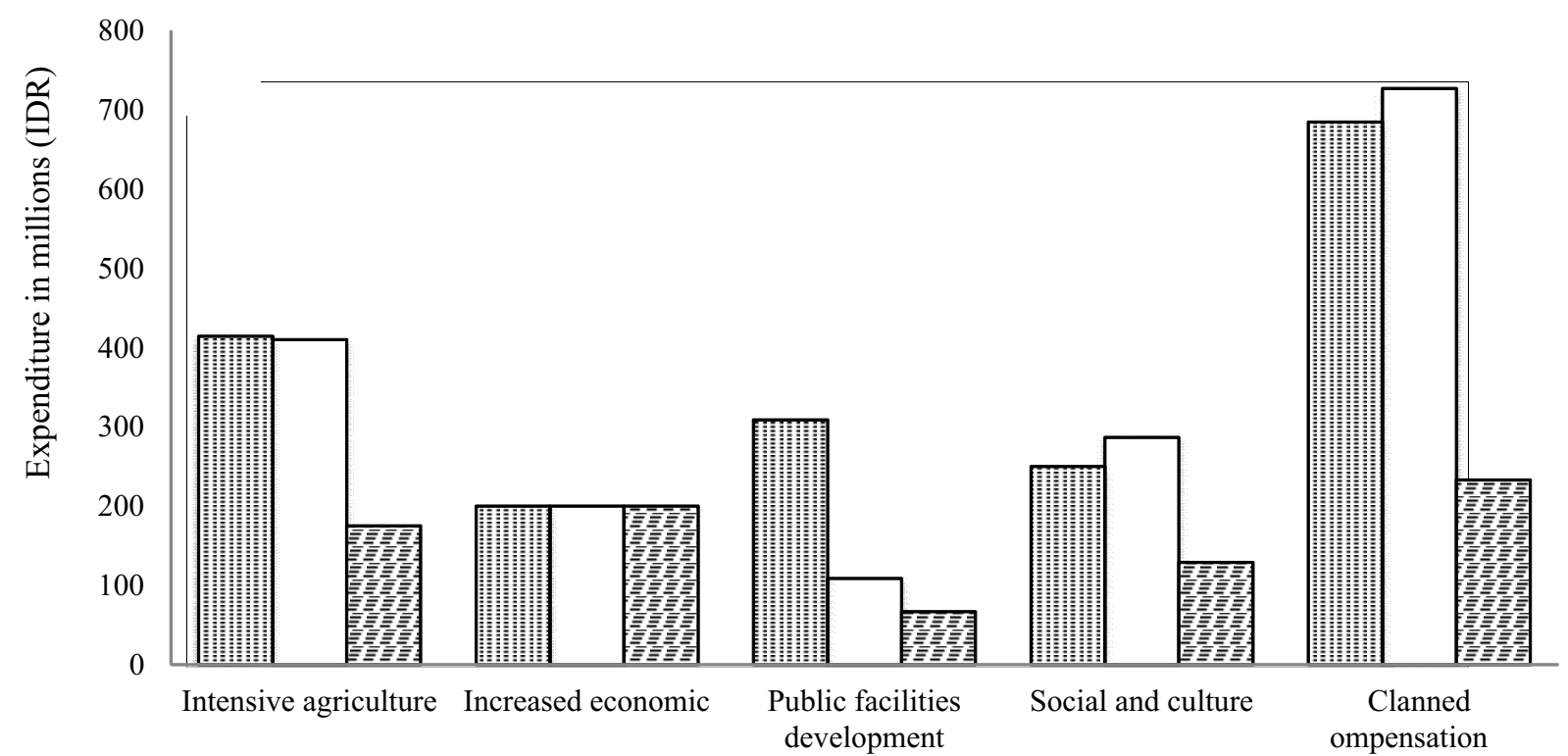

Figure 2 Expenses for customary right compensation and forest village development programs of BUMWI Ltd from 2011-June 2013.2011 (困), 2012 (ㅁ), up to June 2013 (目). 
In Bintuni Bay, however, this $\mathrm{CRC}$ is given in cash at each semester of the following year, and directly distributed into the native clans leader through formal ceremony witnessed by numbers of representative local government officials such as district major and chief security (police and army), village leaders, and native clans leader (petuanan). The petuanan then distribute this compensation to the owner of customary right among the native clans. On this formal ceremony, a letter of handover is officially and formally made, and signed by all representative attendances (BUMWI 2008). In this case, negotiation is not applied for values or types of compensations. After receiving compensation, the local communities are spent their cash instantly, mainly for unproductive spending of tertiary either electronic devices or transportation goods, without considering for children education, saving, health or other activities to generate additional home incomes.

In Papua, there are several types of leaders for indigenous people, ranging from traditional, inherited, religious, to official/governmental leaders, and they have different roles on the community (Tokede \& Wahyudi 2013). Petuanan is inherited leader of several native clans at the indigenous community at Bintuni Bay, while for native clan of Biak at Biak Island is called as Mananwir (Innah 2013), customary leader for Dayak Tribe in Kalimantan (Mulyoutami et al. 2009). Twelve families of native clans, who hold the customary right, have been identified at mangrove forest concession of BUMWI Ltd, such as Kasina, Manuama, Nauri, Fimbay, Fiawe, Kambia, Mariswasi, Naramasa, Wagura, Sarbei, Tugurama, and Werbete (BUMWI 2008). It is quite similar to indigenous community of Dayak in Kalimantan (Mulyoutami et al. 2009).

Forest villages development programs (FVDP) Summaries of expenditure for implementation of FVD Programs for the time series of 1988-2010 and 2011-June 2013 are illustrated in Figure 1 and Figure 2, respectively. It can be highlighted that FVDP have been initiated in 1994 with initial amount of IDR6,300,150.00 (Figure 1). This expenditure increases noticeably from IDR30,814,556.00 in 1996 to IDR663,878,495.00 in 2010, but the highest expenditure was in 2009 for IDR1,199,173,615.00. This expense was actualized into physical, and social facilities development programs, as well as agriculture intensive practices. In detail, FVDP of this mangrove company are such as planting acacia (Acacia spp.) near Babo Airport area, pilot project of cultivation vegetable, supplying seeds of vegetable and fruits to local community, planting medicinal plants at native community garden, building native clan houses, building public facilities (village meeting facilities, traditional market), bridge, wharf, building teacher houses (single and family types), nurse houses, Junior higher school dormitory, and scholarships. The FVDP of this mangrove company are varied, but mostly similar to those of timber companies operated in Papua (Yeny \& Innah 2007), Riau (2011), and Indonesia (Nomura 2008). For the period of 2011-June 2013, the FVDP were grouped into 4, increased economic, intensive agriculture, public facilities development, and social culture programs, respectively (Figure 2). These programs are totally different with those listed in the previous period of 1988-2010. Detailed description of each program is elaborated into the following paragraph.

The main target of increased economic program is to the native clans of Manuama and Nauri. Substantial reasons of increased economic for forest people are not declared clearly. Probably, it is because both native clans are the ownership of Amutu Besar Island, where chip wood industry and base camp are located, and holder majority of customary right of mangrove resources (Wahyudi 2013). As consequence, besides receiving land rental fee of IDR200,000,000.00 annually (Figure 2), these two native clans are the similar targets of FVDP as well. Intensive agriculture programs consist of supplying agriculture tools, equipment for vegetable and fruits cultivation, seeds, fishing tools and equipment, and so on, with nominal value of IDR400 million at average in 2011 and 2012 (Figure 2), and distributed equally among indigenous people at mangrove concession area. Intensive agricultural program is intended to increase the daily income of house family of indigenous people, particularly in fulfilling the daily consumption. However, if the quantity of harvested products is exceed their needs, these agricultural products could be sold to the mangrove company to earn cash or barter with other daily goods (cooking oil, sugar, salts, and soap). Public facilities developments programs are social program initially wished-for establishing a public facilities of villages located the mangrove concession area. Common public facilities are houses, mosque or church, transportation facilities/speedboat body, school dormitory, and constructing bridges and wharfs. Social and culture is program revealed to maintain and sustained the traditional custom and values of indigenous people. For this purposes, this mangrove company offers scholarship, complementary subsidiary of traditional ceremony needs of fuels, goods, and food, hiring community public relation (PR), and offering monthly incentive for Petuanan (BUMWI 2008).

Field implementations of the FVDP at the 4 villages (Irarutu III, Sarbe, Amutu, and Naramasa) in two districts, Babo and Kuri, respectively, have been ensured, and the results are listed in Table 1. This Table shows that majority of the public facilities are in good condition or habitable. Two types of junior high school (SMP) teacher's accommodation, two and three rooms types are designed for un-married and married teacher, respectively. Among FVDP, probably, planting acacia (Acacia spp.) at Babo Airport area is the most tremendous impacts. Before planted with acacia, the surrounding Babo Airport area was a dried-infertile-land, and shrubs and grasses are the dominant. Nowadays, this area is green fully planted with vegetable, fruits, and provides proper environment for living. When this research was conducted, the acacia have an average of diameter of $50 \mathrm{~cm}$ up at diameter breast high (dbh), and they provides appropriate atmosphere for studying at Babo junior high school. However, different FVDP, for example cultivating vegetables and fruits, planting economic oriented crops, raising domestic livestock (goats, cows, and domestic chicken) were no exist or discontinued at the four villages investigated. Majority of indigenous people at mangrove area is forest-dependent dweller, where combination among 
Table 1 Public and social facilities of forest village development programs of BUMWI Ltd recorded at 4 villages (Irarutu III, Sarbe, Amutu, and Naramasa) in 2 districts, Babo and Kuri, respectively.

\begin{tabular}{|c|c|c|c|}
\hline Name & $\begin{array}{c}\text { Location } \\
\text { (village/districts) }\end{array}$ & Condition or statue & Posisition \\
\hline Teacher house (3 rooms) & Irarutu III/Babo & Habitable & $\begin{array}{l}\text { S } 02^{\circ} 32^{\prime} 32.2^{\prime \prime} \\
\text { E } 133^{\circ} 26^{\prime} 33.7^{\prime \prime}\end{array}$ \\
\hline Teacher house (2 rooms) & Irarutu III/Babo & Good & $\begin{array}{l}\text { S } 02^{\circ} 32^{\prime} 35.2^{\prime \prime} \\
\text { E } 133^{\circ} 26^{\prime} 32.2^{\prime \prime}\end{array}$ \\
\hline Acacia (Acacia mangium) & Irarutu III/Babo & $\begin{array}{l}\text { Grow well with diameter of } 50 \\
\mathrm{~cm} \mathrm{up*}\end{array}$ & $\begin{array}{l}\text { S } 02^{\circ} 32^{\prime} 32.2^{\prime \prime} \\
\text { E } 133^{\circ} 26^{\prime} 33.7^{\prime \prime}\end{array}$ \\
\hline $\begin{array}{l}\text { Native clans house (Manuama } \\
\text { and Nauri) }\end{array}$ & Irarutu III/Babo & Habitable & $\begin{array}{l}\text { S } 02^{\circ} 32^{\prime} 34.6^{\prime \prime} \\
\text { E } 133^{\circ} 26^{\prime} 52.7^{\prime \prime}\end{array}$ \\
\hline Mosque & Irarutu III/Babo & Good & $\begin{array}{l}\text { S } 02^{\circ} 32^{\prime} 27.8^{\prime \prime} \\
\text { E } 133^{\circ} 26^{\prime} 49.6^{\prime \prime}\end{array}$ \\
\hline Junior high school dormitory & Irarutu III/Babo & Good & $\begin{array}{l}\text { S } 02^{\circ} 32^{\prime} 32.2^{\prime \prime} \\
\text { E } 133^{\circ} 26^{\prime} 33.7^{\prime \prime}\end{array}$ \\
\hline Bridge and wharf & Sarbe/Kuri & Good & $* *$ \\
\hline Church & Amutu/Babo & Good & $\begin{array}{l}\text { S } 02^{\circ} 32^{\prime} 39.7^{\prime \prime} \\
\text { E } 133^{\circ} 58^{\prime} 24.7^{\prime \prime}\end{array}$ \\
\hline Generator electricity & Naramasa/Kuri & Good & $\begin{array}{l}\text { S } 02^{\circ} 32^{\prime} 39.7^{\prime \prime} \\
\text { E } 133^{\circ} 58^{\prime} 24.7^{\prime \prime}\end{array}$ \\
\hline $\begin{array}{l}\text { Intensive care room } \\
\text { community health center }\end{array}$ & Irarutu III/Babo & Good & $* *$ \\
\hline
\end{tabular}

hunting, shifting cultivation, and rising domestic animal of chicken, goat, and pig are long history tradition and common practices to locally fulfilling self-sufficient and daily necessities (Liu et al. 2012; Tokede \& Wahyudi 2013; Schoneveld 2014). In Papua, semi cultivated tuber crops are the main staple food for the indigenous people (Saraswati et al. 2013), while other nutrients of vegetable, fruits, and proteins mostly harvest from wild forests, and a little effort is undertaken to re-plant or cultivate the daily-consumed plants (Wahyudi 2013).

Hamid et al. (2011) reported that Siak Raya Timber Ltd at Riau Province has several FVDP such as to build public facilities (markets, sanitation, initial road construction, policlinic, schooling rooms, etc), to establish agriculture intensive (vegetable and fruits cultivation, seed and seedling supply, and cultivation demonstration), and to provide employment or recruitment of local worker for forest operation (survey, and enrichment planting). The FVDP somehow are relevant to Principle \# 3 indigenous people`s rights of principles and criteria for Forest Stewardship of Forest Stewardship Council (FSC 2002). It is highlighted that forest management unit (FMU) has social obligation, particularly dealing with the indigenous and local community.

Social-related programs Social-related programs are the programs locally designed to accommodate the social and environmental problems of indigenous communities into company business operation strategy, and the common terms used to describe that company integrate social and environmental concerns into their business operation is called as corporate social responsibility (CSR) (Giannarakis 2011). The main goals of social and environmental concern are to build multiple and trusted-relationship, mutual understanding, cooperation between company and the local inhabitant. Forest companies intensify their CSR related activities and budgets to sustain log-production, forest management sustainability, buyer or customer's trust, and redefine the relationship between companies and society, and to rise financial performances (FP) (Giannarakis 2011; Saeed \& Arshad 2012).

To intensify social relationship to local community, this mangrove company offers innumerable services, such as policlinic for health care program, repair speedboat engine, body maintenances of longboat (long-solid-wood engined boat), and others. For health care, for example, policlinic at base camp Amutu Besar Island serves patients from the indigenous community without any charge. During their staying, patients will be treated equally as company workers including three times of daily regular meals. Number of patient from indigenous people in 2012 was 144 patients or an average of 12 patients each month, and mostly suffering from cold, infection, and malaria (Tokede \& Wahyudi 2013).

To rise household incomes and create alternative jobs for indigenous community, the mangrove company is willing to purchases all agriculture and fishery products, and other traditional material or products from the indigenous community. Summary for the expenditure spending to purchase these products in 2012 are shown in Figure 3. It is illustrated that in 2012 expenditure on vegetables and fruits was the highest (IDR135,719,750.00), followed by mangrove crab (IDR110.766.000,00). These foods are used for daily consumption of mangrove employees at the base camp. Similarly, local community could earn extra income by selling their agricultural product to logging company at Papua (Yeni \& Innah 2007) and Riau (Hamid 2011).

Perception of indigenous people on BUMWI Ltd Majority of the indigenous community have positive views or perception to this mangrove company. To the local 


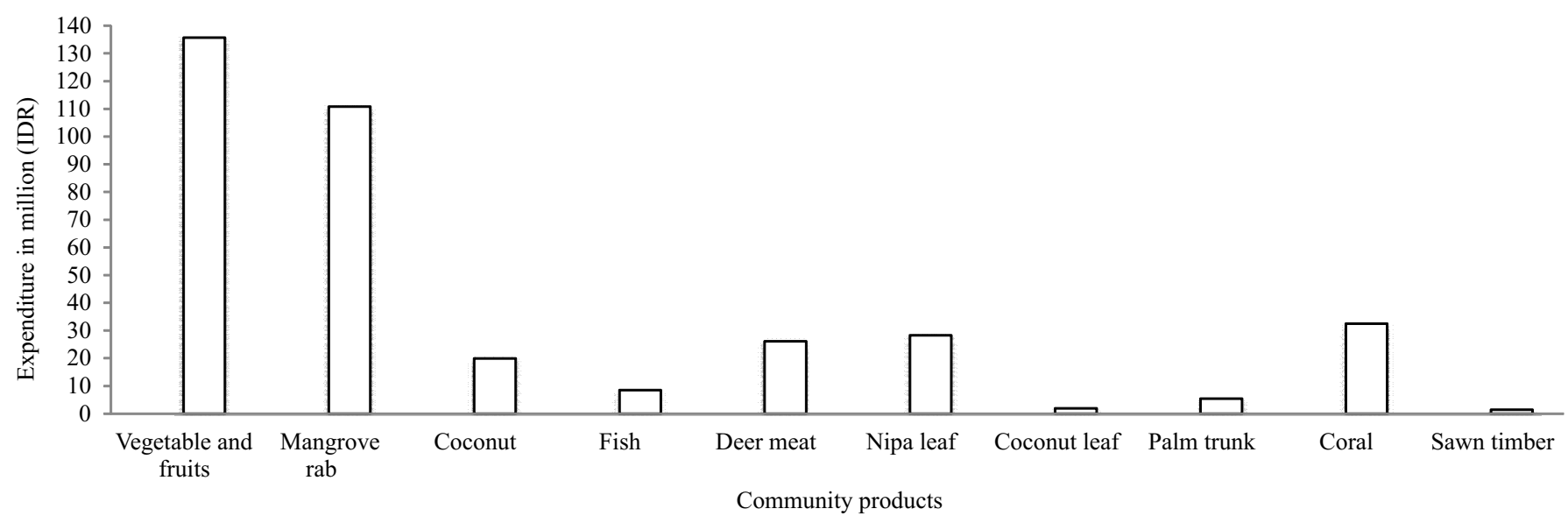

Figure 3 Expenditure of agriculture and fishery products, and others from the native community in 2012.

Table 2 Qualitative assessments of impacts of 25 years operation of mangrove company at Bintuni Bay West Papua on social and economic of indigenous communities.

\begin{tabular}{lcc}
\hline \multicolumn{1}{c}{ Impacts } & Positive & Negative \\
\hline Creating employment & $\checkmark$ & \\
Offering alternative/part time works & $\checkmark$ & \\
Buying agriculture and fishery products & $\checkmark$ & \\
Buying native community material & $\checkmark$ & \\
Receive clanned compensation & $\checkmark$ & $\checkmark$ \\
Offering public facilities & $\checkmark$ & $\checkmark$ \\
Scholarship & $\checkmark$ & $\checkmark$ \\
Allowable access to company facilities & & \\
Sustainable mangrove management & & \\
Social interaction & & \\
Opening new knowledge and innovation & & \\
Dependency on the company help or program & & \\
Indigenous knowledge are getting less practices & & \\
Changing life style and consumerism & & \\
Changing staple food from sago and tuber crops to rice (subsidized rice for poor \\
program)
\end{tabular}

community, harvesting mangrove for chip production create employment, offers extra or alternative job and incomes, develops their village facilities, provide electricity, build school dormitory, scholarships, and so on. BUMWI Ltd has received full of respect from the local community, as the company leader always come to the native community asking for permission before operation, the company always pays compensation on the schedules, build mosque and church, school facility, community health staying rooms, village electricity, and scholarship (Iiyama 2004). More importantly, BUMWI Ltd give a legitimated priority to employs native community, when the native communities are starved they are allowed to eat food and drink in company canteen, and provide health service to native community, and the others.

The indigenous communities have expressed their views that BUMWI Ltd is the kitchen for all indigenous communities, and small company offering huge benefits to indigenous communities (Wahyudi \& Tokede 2013). The first sentence strongly indicates that BUMWI Ltd has been acknowledged, as regular income and livelihood for native community, while the second means that this mangrove company always offer any kinds of helps, assistance and subsidiary to all community, not only to the native clans, but also to all communities.

Impact of mangrove company operation on social economic of indigenous community Qualitative assessments of social and economic impacts on the native community are summarized briefly in Table 2 . It is indicated that the mangrove operation at Bintuni Bay offers numerous positive effects of creating employment, building public facilities, giving scholarship, and the others (Table 2), and mostly create positive impact on local communities. On the other hands, the negative impacts challenged the local community are like heavily dependence on company compensation, local government subsidiary of rise for poor programs, consumerism, changing life, and staple foods 
(Tokede \& Wahyudi 2013).

With emphasis on their expenses, majority of CRC worth was spent for buying un-productive goods, from secondary to tertiary needs, such as buying radio, television, diesel engine, and other optional products (Tokede \& Wahyudi 2013). In contrary, the main purposes of mangrove resources utilization, CRC, and FVDP are to empower and develop the native community for being self-reliant society and increase welfare of local community. Therefore, it seems that local communities are unaware fully the main objectives of CRC and FVDP. Capacity building, absence of local government counselors probably are the most relevant issue responsible in failing these missions. Building capacity would be an alternative approach to strengthen community governance, improve local adat institutions, and raise the income levels of indigenous peoples, and will encounter these negative impacts (Yeni \& Innah 2004; Nomura 2008; World Bank 2012).

\section{Conclusion}

Continued mangrove operation in Bintuni Bay for more than 25 years is remarkable achievement, not only for the mangrove company for chip production sustainability but also for the governments in gathering revenues, taxes, create employment, distribute growth, and development essentially to develop public facilities for the local dependent forest communities. Despites huge amount of compensation being delivered to the local communities together with FVDP, and other CSR program, the local communities remain poor, powerless, and incapable for being self reliant or independent community. Clearly, these facts give the impression that the main goals to empowerment local community are failing trough these programs. With respect to the socio-culture systems, and subsistence agriculture practices, it is highly attainable to alter CRC and FVDP goals by re-orientating from delivering cash and building public facilities to the skilled bases trainings, entrepreneurships, and other related creative or productive activities using their own local resources. This is soundly feasible and achievable for local communities.

\section{References}

[BUMWI] Bintuni Utama Murni Wood Industries Ltd. 2008. Rencana Kerja Usaha Pemanfaatan Hasil Hutan Kayu dalam Hutan Alam pada Hutan Produksi Berbasis Inventarisasi Hutan Berkala Menyeluruh (IHBM) periode tahun 2011-2020.

Cramb RA. 2013. Palmed off: incentive problems with jointventure schemes for oil palm development on customary land. World Development 43:84-99. http://dx.doi.org/10. 1016/j.worlddev.2012.10.015.

Cullen LC, Pretty J, Smith D, Pilgrim SE. 2007. Links between local ecological knowledge and wealth in indigenous communities of Indonesia: implication for conservation of marine resources. The International Journal of Interdisciplinary Social Sciences 2(1):289-299.
Engel S, Palmer C. 2006. Who own the right? The determinant of community benefit from logging in Indonesia. Forest Policy and Economic 8:434-446. http://dx.doi.org/10.1016/j.forpol.2005.08.004.

[FCS] Forest Stewardship Council. 2002. FSC International Standard. FSC Principle and Criteria for Forest Stewardship. FSC-STD-01-001 (Version 4.0- EN). Forest Stewardship Council.

Giannarakis G. 2011. The effects of financial crisis in corporate social responsibility performances. International Journal of Marketing Sciences 3(1):2-10.

[GoWP] Governor of West Papua. 2007. Decree Number 144/2007 for Standard Compensation of Customary Right on Timber Harvested from the Local Clan Community at West Papua Province.

Hamid R, Zulkanaini, Saam Z. 2011. Analysis of socio economic forest village post activity HPH PT. Siak Raya Timber in Pelalawan District, Riau Provinve. Jurnal Ilmu Lingkungan 5(2):130-148.

Iiyama Y. 2004. Community perspective on KDP and other development program: three case studies from forest frontier in Indonesia, West Sumatera, East Kalimantan, and West Irian Jaya. Final draft of project paper for Master of Forestry. Yale: Yale University.

Innah HS, Suharjito D, Dharmawan AH, Darusman D. 2013. Collective action typologies and reforestation in indigenous community of Biak-Papua. Jurnal Manajemen Hutan Tropika 19(1):11-22. http://dx.doi. org/10.7226/jtfm.19.1.11.

Islam Md.S, Wahab Md.A. 2005. A review on the present status and management of mangrove wetland habitat resources in Bangladesh with emphasis on fishery and aquaculture. Hydrobiologia 542:165-190.

Liu J, Zhang R, Zhang Q. 2012. Traditional forest knowledge of the Yi people confronting policy reform and social changes in Yunnan Province of China. Forest Policy and Economic 22:9-17. http://dx.doi.org/10.1016/j.forpol. 2011.12.010.

Marfo E, Schanz H. 2009. Managing logging compensation payment conflicts in Ghana: understanding actorempowerment and implications for policy intervention. Land Use \& Policy 26:619-629. http://dx.doi.org/ 10.1016/j.landusepol.2008.08.009.

[MoF] Ministry of Forestry. 1991. Ministry of Forestry Decree Number 671/Kpts-II/1991 for Forest Concession Village Development/Hak Pengusahaan Hutan Bina Desa.

[MoF] Ministry of Forestry. 1997. Ministry of Forestry Decree Number 523/Kpts-II/1997 for Forest People Development Program/Pembinaan Masyarakat Desa Hutan (PMDH). 
[MoF] Ministry of Forestry. 1999. Ministry of Forestry and Plantation Decree Number 891/Kpts-II/1999 for Bintuni Bay Preserved Area of 24,850.90 ha, Manokwari, Papua Barat.

[MoF] Ministry of Forestry. 2004. Ministry of Forestry Decree Number P.01/Menhut-II/2004 for Empowering The Forest People Living in and or Near the Forest through Social Forestry.

[MoF] Ministry of Forestry. 2011. Statistic Development of Centre for Mangrove Management Region I. Bali: Centre for Mangrove Management Region I Denpasar.

Mulyoutami E, Rismawan R, Joshi L.2009. Local knowledge and management of simpung (forest gardens) among the Dayak people in East Kalimantan, Indonesia. Forest Ecology and Management 257:2054-2061. http://dx.doi.org/10.1016/j.foreco.2009.01.042.

Nomura K. 2008. The politics of participation in forest management-A case from democratising in Indonesia. Journal of Environment and Development 7(2):166-191. http://dx.doi.org/10.1177/1070496507312598.

Nugroho B. 2011. Land right community forest plantation policy: Analysis from institutional perspectives. Jurnal Manajemen Hutan Tropika 17(3):111-118.

Ong JE, Gong WK. 2013. Structure, Function and Management of Mangrove Ecosystems. ISME Mangrove Educational Book Series Number 2. Japan: International Society for Mangrove Ecosystems (ISME), Okinawa, Japan, and International Tropical Timber Organization (ITTO), Yokohama, Japan.

Saraswati P, Soplanit A, Syahputra AT, Kossay L, Muid N, Ginting E, Lyons G. 2013.Yield trial and sensory evaluation of sweet potato cultivars in Highland Papua and West Papua Indonesia. Journal of Tropical Agriculture 51(1-2):74-83.

Saeed MM, Arshad F. 2012. Corporate social responsibility as sources of competition advance: the mediating role of social capital and reputation capital. Journal of Database Marketing \& Customer Strategy Management 19(4):219-232. http://dx.doi.org/10.1057/dbm.2012.19
Schoneveld GC. 2014. The politics of the forest frontier: negotiating between conservation, development, and indigenous rights in Cross River State, Nigeria. Land Use \& Policy 38:147-162. http://dx.doi.org/10.1016/j. landusepol.2013.11.003

Tokede MJ, Wahyudi. 2013. Social impacts of mangrove forest operation in Bintuni. In: Presentation on 25 Years of Mangrove Forest Management by PT BUMWI and its Implication to the Sustainability of Mangrove Ecosystem. Bogor. October 16-17, 2013, Bogor.

Wahyudi. 2013. Non-timber forest products (NTFP's) commodities harvested and sold by indigenous people at local markets in Manokwari, West Papua. In: $2^{\text {nd }}$ International Conference of Indonesian Forestry Researchers 2013, Manggala Wanabakti, 27-28 August, Jakarta.

Walters BB. 2005. Ecological effect of small scale cutting of Philippine mangrove forest. Forest Ecology and Management 206:331-3348. http://dx.doi.org/10.1016/j. foreco.2004.11.015.

Walters BB et al. 2008. Ethnobiology, socio-economics and management of mangrove forests (a review). Aquatic Botany 89:220-236. http://dx.doi.org/10.1016/ j.aquabot.2008.02.009.

Wang Le, Silvan-Cardenas JL, Sousa WP. 2008. Neural network classification of mangrove species from multiseasonal ikonos imagery. Photogrametic Engineering \& Remote Sensing 74(7):921-927. http://dx.doi.org/ 10.14358/PERS.74.7.921.

World bank. 2012. Up to 250,000 Indigenous peoples in Indonesian forest areas to benefit from new Japanese grant, http://www.worldbank.org/en/country/ indonesia/whats-new?qterm $=\&$ displayconttype exact $=$ Press + Release\&lang_exact $=$ English\&os $=120$. (download: January 23, 2014).

Yeni I, Innah HS. 2007. A study on the implementation of forest village community establishment in Papua. Jurnal Penelitian Sosial dan Ekonomi Kehutanan 4(1):73-91. 